\title{
Att urskilja allianser för att hantera osäkerhet
}

\author{
MARITA FLISBÄCK
}

\begin{abstract}
I artikeln undersöks tecken som intervjuade målsägande, tilltalade och vittnen berättar att de tagit till intäkt för att allianser uppkommit under brottmålsrättegång. Urskiljandet av allianser och intervjupersonernas förklaringar till dessa, i termer av klass, kön, ras och sexualitet, tolkas som strategier för att hantera osäkra bedömningssituationer.
\end{abstract}

\section{Inledning}

I det moderna samhället är domstolar en central arena där effektiva beslut ska fattas utifrån kunskap, rationalitet och expertis (Christie 1996, Lindstedt Cronberg 2002). I rättsväsendets arbete, som förväntas styras av saklighet och neutralitet, klassificeras konflikter som fall i syfte att utreda ansvars- eller skuldförhållanden (Jacobsson 2006). För enskilda berörda individer kan bedömningarna verka bekräftande och tas som intäkt för att den egna uppfattningen eller tolkningen av ett händelseförlopp varit sann och riktig. Men aktörerna kan också

Marita Flisbäck, fil.dr sociologi, universitetslektor, Lärarutbildningen, Malmö högskola uppleva dem kränkande om deras berättelse "vederlagts" och känna sig misskrediterade när de uppfattar att den egna verklighetsbeskrivningen inte får gehör (Christie 1996, Sahlin 1998).

Eftersom domstolens primära uppgift är att döma försöker dess ledande aktörer i första hand få en specifik bild av de händelseförlopp som bedöms vara rättsligt relevanta. Det kan göra att komplexiteten i individuella erfarenheter inte beaktas. Om individen upplever att en central aspekt av hennes erfarenheter inte erkänns kan känslor uppkomma av att vara respektlöst bemött, osynliggjord eller missaktad (Margalit 1998, Honneth 2003). Enskildas upplevelse av bekräftelse eller missaktning behöver alltså inte enbart bero på rättegångens utfall. Även temporära gensvar kan vara betydelsefulla. 
I denna artikel undersöker jag enskildas upplevelse av straffprocessuella förhandlingar i brottmålsrättgångar. Jag kommer att argumentera för att det $\mathrm{i}$ vissa fall kan vara mindre väsentligt för tilltalade och målsägande att vinna ett mål än att deras berättelse accepterats och getts en rimlig plats $i$ förhandlingarna.

Med utgångspunkt i intervjuer med målsägande, tilltalade och vittnen behandlar jag intryck av att aktörer i rättssalen under pågående rättegång sökt samförstånd $i$ vad jag benämner allianser. Syftet med artikeln är att undersöka intervjupersonernas beskrivningar av iakttagelser de tolkat som tecken på samarbete, samt försöka förstå de förklaringar de ger dessa och vilken betydelse som tolkningarna haft för att hantera den bedömningssituation de utsatts för under rättegången. Jag argumenterar för att utskiljandet av allianser kan tolkas som ett sätt att skapa en bild av ens egen position i förhandlingarna och att kategoriseringarna av andras gemenskap kan förstås som ett sätt för att orientera sig i en obekant miljö. I det sammanhanget går jag också in på känslor i form av bekräftelse och osäkerhet som de intervjuade framhåller att identifieringen av samarbetet gett upphov till.

Jag har disponerat texten i fyra avsnitt. I det första redogör jag för metod och analytiska utgångspunkter. Därefter följer ett mer empiriskt avsnitt som behandlar signaler som intervjupersonerna säger att de tagit som intäkt för att allianser uppkommit under rättegången. I det tredje avsnittet övergår jag till att visa hur de intervjuade genom att hänvisa till sociala faktorer som klass, generation, släktskap, etnicitet, kön eller sexualitet försöker förklara hur och varför dessa allianser uppstått. En kort avslutning utgör artikelns fjärde avsnitt.

\section{Tillvägagångssätt och analytiska utgångspunkter}

I det följande behandlas kortfattat studiens tillvägagångssätt och metodologiska utgångspunkter. Efter detta introduceras teorier och begrepp som använts i tolkningsarbetet.

\section{Empiriskt material, urval och tolkning}

Artikelns empiriska material bygger på kvalitativa samtalsintervjuer med tre kvinnor och sju män som alla har erfarenhet av förhandlingar i tingsrätt. Fyra av dem har varit tilltalade, fyra målsägande och två personer har kallats till rätten som vittnen. Två av de målsägande har dessutom vittnat i andra brottmål och en av dem har varit stödperson vid ytterligare en förhandling.

Intervjuerna utfördes i slutet av 2005 och i början av 2006 inom ramen för forskningsprojektet Myndigheters trovärdighetsbedömningar, som syftar till att förstå hur trovärdighetsbedömningar påverkar och är relaterade till maktrelationer inom socialtjänst och rättsväsende. ${ }^{1}$ Projektet

1 Forskningsprojektet Myndigheters trovärdig hetsbedömningar (diarienummer 2002-2752) är finansierat av Vetenskapsrådet och har bedrivits och letts av professor Ingrid Sahlin vid Institutionen för socialt arbete, Göteborgs universitet. Under tio månader arbetade jag på halvtid i projektet som biträdande forskare. 
har undersökt enskildas upplevelse av att vara föremål för trovärdighetsbedömningar, samt på vilka grunder handläggare av försörjningsstöd och nämndemän tillskriver klienter, tilltalade, målsäganden och vittnen trovärdighet. Det empiriska materialet utgörs av fokusgruppsintervjuer med nämndemän och handläggare inom socialtjänst, observation $i$ rätten, analys av domar och samtalsintervjuer med klienter, vittnen, tilltalade och målsägande. Intervjumaterialet som ligger till grund för den analys som presenteras här utgör därför endast en liten del av projektets totala empiri. Temat som jag behandlar ingick inte heller direkt i projektets ursprungliga frågeställningar. Alliansers betydelse för förståelsen av rättssalens bedömningssituationer var ett ämne som framkom i samtalsintervjuerna.

Deltagandet i intervjuerna var frivilligt och urvalet av personer gjordes så att flera typer av fall och roller skulle vara representerade. De brottmål intervjupersonerna hade erfarenhet av var stöld, hets mot folkgrupp, brott mot djurskyddslagen, misshandel, ofredande, skadegörelse och olaga hot. Urvalet kan inte ge en generell representation av hur individer upplever att deras trovärdighet bedömts i brottmål. Vad det empiriska materialet bidrar med är att ge en varierande bild av bedömningssituationer med skilda omständigheter och vad tolkandet av allianser kan betyda i dessa olika sammanhang.

Intervjupersonerna hämtades från olika kommuner, skilda tingsrätter och både kvinnor och män kom till tals. I fyra av de tio fallen genomfördes intervjun bara några månader efter rättegången, i de övriga sex hade flera år förlöpt sedan förhandlingarna utspelade sig. Det bör beaktas att skillnaden i tidsperspektiv troligtvis påverkat hur intervjupersonerna redovisat sina upplevelser av de rättsliga förhandlingarna. Trots denna skillnad fanns, som jag återkommer till, likheter i den känslointensitet de gav uttryck för i beskrivningen av upplevelsen av allianser.

Intervjuerna pågick i ungefär två timmar, de bandades och skrevs därefter ut $i$ sin helhet. På några ställen i artikeln har vissa detaljer i berättelserna som rör målen ändrats så att intervjupersonerna ska förbli anonyma. När intervjupersonerna citeras har jag inte angett deras namn utan istället förkortningen "IP", ett nummer samt deras processuella roll.

Min analytiska bearbetning av intervjumaterialet har i huvudsak följt en process som varit uppdelad i fyra led: I en första läsning överblickades intervjuernas sammanhang och mening som sedan sammanfattades i minnesanteckningar. Sedan följde, i en andra fas, konkreta och detaljerade närläsningar där varje mening analyserades. Det tredje steget handlade om att notera särskilda nyckelord som representerade dessa meningarnas specifika innebörd. Dessa ord blev sedan som kategorier riktmärken då jag i det fjärde ledet försökte tolka materialets innebörd på en mer abstrakt tolkningsnivå (jfr Corbin \& Strauss 1990).

Arbetet har dominerats av en induktiv ansats där jag modifierat och modellerat fram teorier utifrån empirins nyansrikedom. Forskningsmetodiskt har jag inspirerats av fenomenologiska angreppssätt genom att så förutsättningslöst som möjligt ta del av intervjupersonernas livsvärld, 
deras känslor och den mening de tillskrivit rättegångserfarenheterna. Detaljerna som de återgivit har väglett min analys när jag försökt förstå deras tolkningsprocesser och emotionellt laddade erfarenheter (Berger \& Luckman 2003, Katz 1988, Honneth 2003). Att förstå den mening människor tillskriver situationer är inte detsamma som att söka efter logiken i deras berättelser. Snarare handlar kvalitativa analyser främst om att uppmärksamma den komplexitet materialet erbjuder genom individens motsägelser och dubbeltydighet (Sennett 2007).

Jag vill poängtera att det empiriska materialet tolkats ur ett sociologiskt perspektiv och därmed varken rör sig inom ett vittnespsykologiskt eller juridiskt vetenskapsområde. Trots det är min förhoppning att artikeln kan bidra med perspektiv på vad som kan uppfattas vara lämpliga genomföranden av brottmålsrättgångar. Det ska dock betonas att analysmaterialet utgörs av samtal och inte observation och att övriga aktörer i de specifika rättegångar som berättelserna gäller inte intervjuats. Detta gör att jag omöjligen kan veta om de allianser som intervjupersonerna skildrat "verkligen" funnits i den betydelsen att fler parter än den intervjuade upplevt dem. Jag kan därför inte säga något om huruvida de aktörer som förstås ingå i en sådan gemenskap själva sett sitt agerande som ett uttryck för samhörighet. Vad jag försökt är att lyfta fram intervjupersonens perspektiv och i analysen av deras berättelser styrts av en fenomenlogisk strävan efter att "förstå för förståelsens egen skull«(Berger 1992 s. 23).

\section{Rättssalens allianser, takt och interaktion}

I tolkningsarbetet har utgångspunkten varit att trovärdighet inte är en egenskap personer "har" utan något människor konstruerar i specifika bedömningssituationer och institutionella kontexter som exempelvis en rättegång. Tidigare forskning har framhållit att aktörernas livshistoria och framtidsplaner ofta får stor betydelse när rätten värderar trovärdigheten $i$ en berättelse (se t.ex. Viano 1996, Hydle 2000, Ekström 2002). Rättssalen kan betraktas som en plats där målsägandes, tilltalades eller vittnens nutida jag länkas samman med förflutna och framtida skeenden. Utifrån Erving Goffman (2000) analyserar jag därför rättssalen som en scen där känslor och händelseförlopp spelar en avgörande roll både för aktörernas framtid, deras aktuella självbild och hur de bedömer att andra aktörer ser på dem.

Det som i artikelns benämns wallianser« kan liknas vid vad Goffman kallat det sociala livets team, d.v.s. grupperingar som bildas genom att människor gemensamt anstränger sig för att hävda och upprätthålla en definition av en social situation. Likt team verkar allianser som en "sammanhållande kraft» (Goffman 2000 s. 77) grundade $i$ en gemensam tro på en given verklighetsskildring. Både andras och eget teamarbete kan ge upphov till en känsla av att kunna - eller inte kunna - påverka utfall och förlopp som i exempelvis en rättegång.

Team kan vara tillfälliga eller grundade i en längre gemensam historia, men bör främst förstås som ett resultat av de roller individer intar i en viss kontext. De allian- 
ser som upprättas i rättssalen inbegriper på liknande sätt både rättegångens tillfälligt berörda aktörer och anhöriga åhörare.

För att kunna ingå $i$ ett team, liksom urskilja och förstå andras lieranden, behöver individen besitta en taktkänsla där hon är receptiv för den respons andra aktörer ger på hennes agerande. Goffman (2000) menar att vi människor generellt drivs av viljan att göra intryck på vår omgivning. Att försöka få grepp om den aktuella scenens sociala spelregler blir då en förutsättning för att förstå hur vi bäst ska agera, ett tolkningsarbete som i sin tur baseras på hur vi uppfattar andras intryck av oss själva.

Utifrån resonemanget kan antas att inblandade aktörer i en rättegång stundtals anpassar sin berättelse och iscensätter sitt beteende så att det ska verka övertygande utifrån framgångskriterier de uppfattat vara gällande. Att klienter, åklagare och försvarare kan vara väl medvetna om vilka kriterier som anses avgöra någons trovärdighet, och på vilket sätt de ska agera för att uppnå dessa, har t.ex. Simon Ekström (2002) pekat på i sin avhandling om svenskt rättsväsendes hantering av våldtäktsbrott 1946-1950. På liknande sätt har Robert Emerson (1996) skildrat hur frivilligarbetare hjälpt våldsoffer att utforma ansökan om besöksförbud efter vad erfarenheten lärt dem att åklagare och domare anser vara trovärdiga händelseförlopp och ageranden.

\section{Känslor, exkludering och erkännande}

När de som intervjuats i samband med denna studie säger att de under rätte- gången urskiljt olika allianser har jag tolkat det som en strategi för att förstå hur det egna agerandet uppfattas, hur väl det stämmer in i miljön och som ett sätt att få grepp om hur den egna utsagan bedömts. Enligt min mening är det dock felaktigt att förstå urskiljandet av allianser som medvetna strategier för att vinna målet. När de intervjuade identifierat en allians, och säger de att de känt sig inkluderade i denna, uttrycker de känslor av bekräftelse. Upplevelser av exkludering har på motsatt vis gett upphov till osäkerhet med känslor av att den egna berättelsen förts fram i ett tomrum utan respons.

Utöver Goffmans förnuftsorienterade interaktionistiska perspektiv har jag i analysen även använt mig av Jack Katz teorier om samspelens känslomässiga villkor (jfr Åkerström 1996), samt Axel Honneths beskrivning av människors strävan efter erkännande. När vi bygger upp vår självbild genom att förstå hur vi ter oss $i$ andras ögon så är det, enligt Katz (1996, 1999), inte en reflexiv och kalkylerande process utan en praktisk känslogrundad dynamik. Honneth (2003) menar att individen känner sig missaktad vid upplevelsen av att någon medvetet ignorerat aspekter av personligheten som hon själv anser väsentlig. Oförrätten ligger i att individen känner att hon i samspelet misslyckats med att nå erkännande för denna centrala sida av självet.

Utgångspunkten i denna artikel är att individer i rättegångssammanhang uppfattar sin upplevelseskildring av ett brott som en betydelsefull aspekt av sin personlighet och därför ger stor betydelse vid erkännandet av denna (Christie 1996, Sahlin 1998). 
Att identifiera allianser kan bli ett sätt för individen att förstå om - och i så fall vilkaaktörer i rättssalen som ställer sig bakom verklighetsskildringen eller misstror hennes berättelse.

\section{Samspel i rättssalen som signalerar allianser}

Den interaktion intervjupersonerna sett som tecken på att vissa av rättssalens aktörer allierat sig med varandra kommer att behandlas i de avsnitt som nu följer. Dessa tecken handlar om explicit tal, gester, blickar och skratt eller hur aktörer fysiskt placerats på den scen som rättssalen kan betraktas som.

\section{Rättssalens inramning och spelregler}

Utifrån Goffmans (2000) perspektiv har den scen som tingsrättsförhandlingarna utspelar sig på en inramning som vittnar om teamens sammansättning. Inramningen kan även säga något om teamens olika maktresurser. Intervjupersonerna säger att de tolkat placeringarna i rättssalen som uttryck för att aktörer varit i allians. De beskriver också hur den fysiska placeringen påverkat deras uppfattning om olika grupperingars inflytande. Att sitta högt upp, som nämndemän och juristdomare ibland gör i rättssalar, ses som ett uttryck för makten att döma i målet, att ha kontroll över rättegångens agenda och spelregler. Att konfliktens parter, d.v.s. målsägande och tilltalade, i likhet med vittnen, placerats på en golvnära nivå signalerar däremot en mindre resursstark position.

Nämndemännen och domaren hade man ju inte någon kontakt med egentligen. De sitter ju ganska högt upp ... Det är väldigt tydligt /.../ Man kan känna sig liten nästan /.../ Om inte jag minns fel så, det måste nästan ha varit två, tre meter upp, kändes det som, som de sitter. Det blir en väldigt tydlig markering ... (I: Ja?) Överheten, på något sätt. (IP2, målsägande)

Utifrån rummets utformning och möblering har de intervjuade funnit två typer av allianser: bedömare och bedömda, där de med makt att bedöma konflikten avskiljts från de inblandade som ska återge vad den handlat om. Ett sådant fysiskt avstånd har dessutom fört med sig en mental distans och en intervjuperson skildrar nämndemän och juristdomaren som "någon sorts olympiska gudar, där vi liksom är de vanliga människorna" (IP1, målsägande/vittne). Bedömarnas kroppar förstås som en förlängning av en makt inbyggd $i$ arkitekturen. Intervjupersonen säger sig ha hört att detta är mer märkbart i högre instanser:

Jag vet inte om det stämmer, men det var någon som sa, som hade varit i högsta domstolen, att där nådde man inte ens ... när man väl sitter i de där stolarna så når man inte ens golvet. (IP1, målsägande/vittne)

Vid en första anblick kan det framstå som motsägelsefullt att betrakta bedömare och bedömda som två olika allianser då de bedömda inbördes tycks drivas av olika intressen i konflikten. Men gruppering- 
arna blir mer begripliga då de sätts samman med maktresurser i form av institutionell erfarenhet. Intervjupersonerna har uppfattat att juristdomare och nämndemän, men även åklagare och advokater, besuttit betydligt större information om rättegångens spel än de själva.

Nu efteråt så kan jag ju konstatera att det inte fanns någon vägledning över huvud taget för mig, som så ung person. Och jag vill nog ... av det drar jag slutsatsen att, jag tror det är liknande vare sig det är unga människor eller människor som inte tidigare har haft erfarenhet av mötet med myndigheter, eller människor som inte har så mycket utbildning, jag tror att ... Man fär ingen vägledning, eller man fär väldigt lite vägledning, om vad det är som händer. (IP1, målsägande/vittne)

I intervjuerna framställs rättegången som ett tillfälle där målsägande, tilltalade och vittnen som »dem där nere« varit i händerna på en allians av bedömare. Enligt Goffman (2000) är det ofta så att ett av teamen har större kontroll över scenens inramning än det andra. Snarare än att själva agera aktivt tenderar gruppen med mindre kontroll att reagera på den dominerande gruppens agenda och aktiva ageranden. Detta team har alltså svårare att definiera situationen, kontrollera förlopp och utfall. På liknande vis har bedömarna under rättegången en kunskap om hur spelet i rättssalen går till. Detta ger dem inte bara kunskap om hur situationerna bäst ska hanteras utan också en förmåga att förutse vad som kommer att hända. De intervjuade menar att detta övertag underbyggs av förhandlingens inramning och ger upphov till känslor av osäkerhet, att vara liten och obetydlig.

Man var mitt på alltihopa, men jag kommer inte ihåg om detta var $p a ̊$, om den känslan var $i$ tingsrätten eller $i$ hovrätten, men bara det att jag sitter här: Den lilla, lilla och sedan alla de andra är där runt omkring. Alla de andra vet vad det handlar om, vad som har hänt innan och vad som kommer att hända efterä liksom. Jag vet bara det som jag kan säga ... Ingenting. (IP9, vittne)

Väntan eller oklara besked kan framkalla en genomgripande oro med rädslan inför att vad som helst kan ske, när som helst (Bourdieu 1996, Löfstrand 2005). I en rättegångssituation kan sådana osäkerhetskänslor förstärkas genom väntan innan aktören tillåtits göra entré på rättssalens scen, vilket skildras av intervjupersonen nedan.

Det var nog den längsta pärsen jag haft någon gång innan jag kom till den rättegången. Det kändes ju som år innan jag fick komma dit. Jag visste ju att det finns väl inget värre än att komma in i en rättssal och bli anklagad för någonting och gå och vänta på den tiden. (IP6, tilltalad)

För vittnena tycks oron ha ökat genom en extra lång väntan innan de kommit in $\mathrm{i}$ rättssalen. Ett vittne beskriver hur han, när han väl inkallats till rättssalen, får avvakta med att avlägga ed och vittnesmål eftersom "domaren och nämndemännen småpratar och grejar", men "till sist så lägger han [juristdomaren] ifrain sig och tittar upp" (IP1, målsägande/vittne). I ett sådant sammanhang kan tendensen att klassificera alli- 
anser bli ett sätt att orientera sig i rättssalen och undvika liknande osäkerhetskänslor.

Ett annat vittne berättar att han aldrig förstod varför han kallats till rättegångarna eller vad konflikten handlat om, men att han som strategi för att förstå sammanhanget försökt att utläsa vem som var åklagare, försvarare och vilka som åtalats. Han säger att han ansträngt sig för att via rättssalens inramning få grepp om de inblandade aktörerna status och gemensamma intressen. Rekonstruktionen av rättssalen och de olika aktörernas placering beskrivs i intervjusamtalet fortfarande med osäkerhet och förvirring.

Han [försvarsadvokaten] satt mycket mer till vänster ... framför mig till vänster liksom, så det var det inte heller. Ja, jag ... jag fick aldrig nagon klarhet $i$ vad som var vad ... En [bänk] som var svängd àt det haillet ... Nej, det var nog så (visar), då satt de vid ... $i$ rad då, de båda åtalade, som satt närmast dörren. Jag kom in här borta vid ändan på deras bänk då och så fick jag stå framför där först, för att avge någon ed, och så fick jag sätta mig i en bänk framför allting. (IP3, vittne)

\section{Allianstillhörighet uttryckt via tal}

Ida Hydle (2000) har hävdat att de mångfacetterade känslor som väcks i samband med förhandlingarna till stor del undertrycks eftersom rättegången har mycket bestämda regler för samspel, tal och information. Att dechiffrera rättssalens inramning kan då vara ett sätt för att förstå vad som kommer att hända, vilka som ingått allians och med vilka resurser. I intervjuerna framkommer att gester och tal i det sammanhanget kan vara mer konkreta tecken på allianstillhörighet än placeringen i rummet.

Ett vittne säger att han visserligen fann det svårt att förstå vad som hände under rättegångarna, men att han trots allt kunde identifiera en allians bestående av advokaten och de tilltalade eftersom advokaten i sina frågor tydligt visade sig kritisk mot hans vittnesmål. Talet signalerade en vilja att driva de tilltalades perspektiv och stå bakom deras verklighetsbeskrivning.

Jag satt $i$ mitten och så hade jag allihop $i$ en rad framför mig då. Och vilken som var vilken där, det hade jag ingen som helst aning om, men jag förstod vem som var deras försvarsadvokat för den gav sig på mig stenhårt. (IP3, vittne)

Ovan framkommer en föreställning om att vissa aktörer inkluderas i en allians genom att andra parters verklighetsbeskrivningar ifrågasätts. På liknande sätt berättar en målsägande kvinna att domaren ställde frågor till henne som gjorde att hon kände att hennes utsaga betvivlades. Kvinnan, som tidigare varit sambo med mannen som stod tilltalad för ofredande, olaga hot och skadegörelse, säger att hon uppfattade att domaren och den tilltalade under rättegången hade en särskild gemenskap. Denna visade sig bl.a. genom att domaren infantiliserade hennes beskrivning av händelserna och då indirekt understödde mannens verklighetsskildring.

Det känns liksom som en sorts konstig lek. Jag upplevde domaren som: 'Jaha, så ni var 
lite kära ibörjan då?', när de pratade om vår relation, hur den var och jag vet inte. (IP4, målsägande)

Även känslan av att själv inkluderas i en allians kan förstärkas genom tal. Beröm eller uppmuntrande kommentarer från exempelvis en domare kan tas som intäkt för att bedömarna står bakom den beskrivning aktören gett av ett händelseförlopp. Tillsägelser eller kritiska kommentarer till motparten kan tas som tecken på att bedömarna betvivlar den personens utsaga. Detta skildras av en intervjuad målsägande som uppfattat att hans beskrivning av händelserna kring brottet varit den rätten ansett mest trovärdig.

Jag blev mer och mer självsäker under rättegången, att man kände att 'det här är liksom, det är snart över, det här kommer bara att kunna gå åt ett håll', kände man, när man satt där, och när han [den tilltalade] började bli ifrågasatt också av ordförande på slutet. (I: Ja?) Vilket gör att hon [ordförande] är ju mer så där /...: 'Vad bra att ni verkligen', till mig då, tror jag att hon sade, något sådant att jag 'har tagit mig tid och åkt ner här för att vittna', liksom. Men hon känner samtidigt också att det skulle inte behövas något sådant här, alltså att det har gått så långt att han [den tilltalade] kan sitta och ljuga, för det blir så tydligt för alla i rätten att han sitter och ljuger. I.../ Hon säger någonting i stil med, det kommer jag ihåg väl, när rättegången börjar ta slut, att hon blir på något sätt: 'Han sitter här och ljuger så uppenbart inför rätten'. (IP5, målsägande)

Kampen om trovärdighet i rättegångar kan ofta få karaktären av ett nollsummespel.
Det den ena parten vinner i trovärdighet förlorar den andra (Sahlin 1994, 1998, Ekström 2002). Den intervjuade ovan säger att han upplevde att han fick mest gehör för sin version eftersom den tilltalade vid flera tillfällen ändrade sin berättelse och framförde motsägelsefulla uppgifter. Även försvarsadvokaten gjorde intryck av att till slut upphöra att tro på sin klient och vid slutet av förhandlingen var den tilltalade, enligt intervjupersonen, helt allianslös och hade singen på sin sida där inne /.../ förutom sin pappa som sitter där" (IP5, målsägande).

Även om den målsägande i fallet ovan under hela rättegången fann sig inkluderad $i$ en allians med bedömarna beskriver flera andra intervjupersoner hur de under en och samma rättegång upplevt sig som både inkluderade och exkluderade av samma aktörer. Den målsägande kvinna, som känt att hennes vittnesmål inte togs på allvar eftersom hon uppfattat att domaren och den tilltalade under rättegången lierat sig med varandra, säger att domaren "ändå" vid ett tillfälle verifierat hennes verklighetsskildring genom att uttala tvivel inför mannens uppgifter.

$N N$ [den tilltalade] nekade ju liksom till allting då, och då säger ändå domaren: 'Men du kan ju inte neka till de här sms:n?' Och då erkänner han, tror jag, ett, eller något sådant. (IP4, målsägande)

En annan liknande temporär inkludering återges av en intervjuad som åtalades för hets mot folkgrupp. Intervjupersonen dömdes visserligen för brottet, men upplevde sig en kort stund under rättegången $\mathrm{i}$ en allians med åklagaren. Detta skedde när 
ett vittne, med en annorlunda beskrivning av händelserna kring brottet, ändrade sin historia.

Han [åklagaren] ställde den frågan två gånger: 'Du har ju uppgett $i$ rapporten $i$ ditt förhör...' och så sa han vad han hade sagt då. 'Ja, men nu är det ju så länge sedan. Jag kan ju ha glömt det.' 'Men du kan ju inte glömma sådant? Du har ju uppgett i rapporten. Har du hört det eller inte?' 'Nej, men det har jag inte', sa han. /.../Han [åklagaren] sa de frågorna två gånger. Det tyckte jag var starkt gjort, att han gjorde. Då märkte jag att då satte han en press på den här gubben [vittnet], att 'nu måste du hailla dig till sanningen', tyckte jag. 'Du kan inte säga så en gång och sedan helt plötsligt har du inte varit där.' Så att jag tyckte att han sa det på ett sådant fint sätt att jag fick känslan av att jag fick medhaill. (IP6, tilltalad)

Tidigare studier har visat att ändringar i vittnesmål bland poliser, domare och nämndemän ofta ses som ett underförstått tecken på att historien inte är sann (Scheppele 1994, Strömwall \& Grönhag 2003, Strömwall et al. 2004, Sahlin 2008). Intervjupersonen säger att åklagaren tog hans version av händelsen på större allvar genom att vittnet förlorade trovärdighet just genom att ändra sin berättelse. Den kortvariga alliansen visade sig genom åklagarens starkt ifrågasättande tal mot vittnesmålet.

\section{Allianseruttrycktavia blickar och skratt}

De intervjuade ger också uttryck för att de använt sig av blickar för att markera samhörighet och exkludera andra aktörer. De har även uppfattat att andra aktörer använt ögonuttryck på detta sätt. Intervjupersonen (IP6, tilltalad), som upplevt en tillfällig allians med åklagaren, beskriver hur han besvarade inviten till gemenskap genom att just spänna blicken i vittnet när detta förhördes. Den intensiva blicken understödde åklagarens frågor så att de gemensamt skulle få fram »sanningen«.

Jag satte ögonen i honom [vittnet] hela tiden medan han fick sina frägor och då vred han sig många gånger och kom inte ihåg riktigt: 'Det är ju så länge sedan.' (IP6, tilltalad)

Ögonkast kan bli ett medel för att framhäva alliansers styrka och markera att "sanningens representanter" enats medan "lögnare» exkluderats. En målsägande (IP5, målsägande) i ett misshandelsmål säger att även om den tilltalade efterhand sänkte sin blick så hade den tilltalade tillsammans med sin pappa intensivt tittat på intervjupersonen för att visa att de stod enade bakom den tilltalades version av händelsen.

Ganska mycket sitter han [den tilltalade] och tittar ner. Men han, till att börja med, så sitter han på något sätt och blänger också. Hans pappa sitter liksom och kollar /.../ Och jag vet inte vad han tror egentligen. Om han, han tror säkert på sin son. (IP5, målsägande)

Genom att signalera hur lögnaktig en berättelse uppfattas vara eller hur skamligt ett brott är kan blickar betraktas som ett moraliskt laddat vapen som appellerar 
till "högre", "goda" värden (jfr Katz 1988). En av de intervjuade tilltalades först för skadegörelse och vid ett senare tillfälle för rån. Då han jämför rättegångarna säger han att nämndemän och åhörare vid den senare rättegången särskilt vässade sina blickar för att markera en gemenskap uppbyggd på ett samfällt avståndstagande från brottet.

Man gick mera igenom vilken ondperson jag nu måste vara. I fallen där det bara var ren skadegörelse på materiella ting så var det mer summariskt så där att 'okej, så mycket kostade det, bla, bla, bla, bla', och sedan var det ganska summariskt så när, och det var inte så känslosamt. Men i de fallen när det fanns fysiskt målsägande personer på plats och så där så, så blev det ju mer rotande $i$ vilken ond person jag måste vara, eller mer fokus på det. Det kändes som att de tittade merpå en. (IP7, tilltalad)

Intervjupersonen ovan upplevde att åhörare, juristdomare och nämndemän betraktade honom som "ond", en "värsting" vars handlingar låg långt ifrån deras syn på vad som är godtagbart.

Intervjupersonerna kan skildra hur de under rättegången kastats in i stereotypa bilder av offer och förövare. Exempelvis säger en intervjuad man, tilltalad för brott mot djurskyddslagen, att han utpekats som "någon jävla sadist som njöt av att plåga djur" (IP8, tilltalad).

Nils Christie (2001) har hävdat att brott ofta förenklas i kategoriska bilder av den typiske gärningsmannen och det ideala offret. Människors önskan att avskilja brott från sitt eget vardagsliv och handlande gör att de många gånger bortser från komplika- tioner, såsom att gärningsman och brottsoffer exempelvis kan vara samma person (även Sahlin 1994).

Skratt och utbyten av leenden kan av intervjupersonerna framställas som tecken på att olika aktörer mer eller mindre omedvetet försökt att förankra en allians. Intervjupersonen nedan säger att bedömarnas allians visat sig när juristdomare och nämndemän skrattat åt detaljer i olika vittnesmål som rörde honom.

Men jag minns ju det väldigt starkt, hur jag sitter där och hur jag har mina föräldrar bakom mig, och jag skäms ju så inför dem, när någon berättar den här historien och det som händer sedan är ju att alla dessa nämndemän, de börjar ju inte småskratta eller någonting, utan de rågarvar, gör de. (IP1, målsägande/ vittne)

Katz(1999) har beskrivit skratt som en intersubjektivt grundad känsla som tydligt signalerar samhörighet mellan människor genom att inbjuda till en intellektuell och lustfylld rörelse mellan flera olika sätt att förstå en person och dennes situation. Jag menar att skrattet förutom att markera två eller flera personers samröre erbjuder en länk till ett mer komplext ıjag" utöver det som framställs på rättegångens scen. Skratt kan bli en väg till tolkningar bortom stereotypa bilder av "förövare« eller »offer«. I intervjusamtalen framkommer dock att när motparten skrattat tillsammans med andra aktörer så har det tagits som intäkt för att motparten blivit bekräftad och bedömts som mer trovärdig än man själv. Detta beskrivs av intervjupersonen som varit målsägande $\mathrm{i}$ rättegången mot sin före detta sambo. 
Det fanns skratt med, lite så där käckt. Vad heter han som ... domaren var så där så att han skojade till det lite och det var det där, det är det ... 'Jaha, så ni var lite vänner emellanåt då?' /.../Och skojade lite med NN [den tilltalade] där. (I: Jaha?) Han var kanske lite så där en skojfrisk domare, det vet inte jag, men jag kan inte stå... Det här, det här är mitt liv. Jag har en dotter. Det är hennes liv. (IP4, målsägande)

Intervjupersonen uppfattade att domarens och den tilltalades gemensamma skratt inte bara var ett tecken på att de ingått en allians utan också indikerade att hennes verklighetsuppfattning inte tagits på fullt allvar av bedömarna. Snarare gav domarens skratt intryck av ett ironiserande kring den tilltalade som "förövare». Om de intervjuade beskriver att gemensamma fördömanden av en förövare eller lögnare visat sig med hjälp av blickar, så kan alltså skratt snarare uttrycka misstro kring att en aktör skulle vara förövare eller offer.

\section{Hur allianser förklaras}

I intervjupersonernas utsagor förefaller knappa kunskaper om rättegångens spelregler, tillsammans med väntan och osynlighet, bidragit till att utveckla särskilda metoder för att tolka dessa osäkra situationer. Den metod som beskrivits ovan handlar om att identifiera gemenskaper i rättssalen. Men de intervjuade stannar inte vid att urskilja allianser utan formulerar också teorier om vad de ser som grunden till samhörigheten.

Katz (1999) menar att människor, som ett sätt för att få upprättelse eller uppnå kontroll i utsatta lägen, tenderar att klassificera andras och eget beteende utifrån en generaliserande förförståelse om samhällsgrupper. På liknande sätt visas nedan hur de intervjuade tar hjälp av en generaliserande förförståelse för att tolka alliansernas uppkomst. Allianserna beskrivs som uttryck för maktformationer grundade på social kategoritillhörighet som etnicitet, sexualitet, kön, ålder eller social klass.

\section{Klass och generation}

Två förklaringar som de intervjuade uppger till alliansernas uppkomst handlar om social klass och generation. Den respekt och förståelse som de berättar att exempelvis juristdomare, nämndemän, åklagare eller advokater visat inför någon av rättssalens aktörer kan hänföras till att personen tillhör samma övre medelklass eller generation som de anser att rättens ledamöter är medlemmar av.

En intervjuperson (IP1, målsägande/ vittne) säger att den aktör som i tal och rörelse kan återspegla "den samhällsklass nämndemännen själva tillhör eller strävar efter att tillhöra» har bättre förutsättningar att få gehör för sin verklighetsbeskrivning genom att inkluderas i en klassgemenskap. Att däremot, som han själv en gång gjort, stoppa händerna i byxfickorna kan leda till en reprimand och exkludering då agerandet är tecken på arbetarklasstillhörighet.

Ju mer skolad man är $i$ att följa en borgerlig konvenans, desto större chans har man att bli trodd. Man ska veta en sådan sak som att man inte stoppar händerna i fickorna, att 
det gör man inte, sådant gör arbetarklassen. (IP1, målsägande/vittne)

Intervjupersonen hävdar att han även upplevt utanförskap som går att återkoppla till generationstillhörighet. Som ung målsägande i ett misshandelsmål säger han att bedömarnas gemensamma skratt inte enbart signalerat en arbetsgemenskap, utan också grundat sig i en åldersallians med liten vördnad inför unga människor.

Att som tonåring möta en värld utav myndiga nämndemän och domare och åklagare och deras brist på respekt för unga människor /.../ Det gjorde ju att jag, då var jag bara 16 år och, men då liksom väldigt tydligt fick jag en väldigt stark skepsis till rätts ... till domare och nämndemän. (IP1, målsägande/ vittne)

För de som varit unga vid rättegångstillfället skildras rättegången stundtals som ett kallt och ensamt möte med vuxenvärlden. En kvinna säger att wrätten ju representerar väldigt tydligt, för det är liksom, det är liksom vuxen-vuxen, med stort $V$ «(IP10, tilltalad). Kvinnan beskriver i intervjun hur hon under rättegången kände förvirring, utanförskap, ensamhet och hur hon försökte att söka någons blick, men »ingen log tillbaka« (IP10, tilltalad). Känslan av utanförskap förklaras implicit med klass- och generationsskillnader. Ett sätt för att inkluderas i de äldre bedömarnas allians var då att iklä sig kläder som kvinnan föreställde sig skulle stämma överens med den respektabilitet som var passande i rättssalens "vuxna värld" (IP10, tilltalad).
Jag tog liksom min absolut fina ... Så där, du vet ... vit blus med liksom så här lite röda kanter, som jag hade köpt i Paris, och så en sådan här liten rosett man knyter, lite sidenmaterial. (IP10, tilltalad)

Enligt Goffman (2000) förstärker människor sina självpresentationer genom att ta hjälp av viss rekvisita i sina framträdanden. På så sätt kan t.ex. val av kläder betraktas som en önskan om att tillhöra ett visst team. Klädval kan alltså bli försök att med hjälp av rekvisita uppvisa en strävan efter att bli inkluderad, bekräftad och lyssnad på i den äldre generationens allians. Den målsägande mannen ger uttryck för liknande erfarenhet när han säger att "fast jag var 16 år så hade jag då vit skjorta, slips, väst och kavaj»(IP1, målsägande/vittne).

\section{Släktskapoch inte svensk som "de andra"}

Utöver klass och generation kan släktskap, ras och etnicitet användas för att förklara varför allianser uppkommit i rättssalen. Allianser uppbyggda på släktskap uppfattas som så stabila och lojala att de bibehålls hur "ond" en person än antas vara eller om en allierads berättelse bryter mot uppfattade trovärdighetskriterier som krav på koherens. Exempelvis säger den målsägande (IP5, målsägande), som i rätten menade sig ha sett hur alla aktörer och åhörare slutat tro på den tilltalade, att det bara var pappan som inte tappade tron på sonen som åtalats. Kvinnan nedan, som varit sjuksköterska, stod åtalad för att ha bestulit sina vårdtagare. Hon uppfattade att de andra par- 
terna i rättssalen enades i synen på henne som ond förövare och säger att den känslan förstärktes av gemenskapen mellan de målsägande och deras anhöriga.

Släkt till de här målsägande, som tyckte att det var ett fruktansvärt, det här liksom att jag hade stulit hemma hos de här gamla människorna. (IP10, tilltalad)

Generellt skildrar kvinnan upplevelser av utanförskap under hela rättegången, men hon säger att en familjemedlem i publiken ändå fanns där som en lierad stödperson:

Min syster då, som är fem år yngre liksom, hon satt där längst bak $i$ rättegångssalen liksom som enda sällskap. (IP10, tilltalad)

Den förklaring kvinnan ger till utanförskapet sätter hon samband med sitt utomeuropeiska utseende.

Med mitt annorlunda utseende, så som andra ju tänker mycket lättare på än vad jag själv, vad jag själv gör som adopterad, och tror liksom att man ser ut som alla andra, men det gör man ju inte, så det måste ju liksom på något sätt ha funnits. (IP10, tilltalad)

Liknande utanförskap förklaras av ett intervjuat vittne som säger att hon blev missförstådd eftersom hon har bristande svenskkunskaper.

Det behövde inte vara någon stor sak, men liksom ändå så att jag upplevde det som att de har liksom inte fattat riktigt vad jag menar /.../Men jag är ju van att folk förstår mig inte riktigt. På grund av språket och så, att jag kanske inte fätt fram det som jag riktigt ville. (IP9, vittne)

Vittnet poängterar dock att hennes berättelse till slut beaktades, "att de [jurister och nämndemän] accepterade liksom, så att det var en missuppfattning" (IP9, vittne). Trots detta återger hon missförståndet som en situation där hon kände sig liten och ensam.

Enligt Howard S. Becker (1998) finns en "trovärdighetshierarki» som innebär att personer med hög status och stora maktresurser ges företräde i att bedöma och tolka situationer. En sådan "trovärdighetshierarki« utgör för de intervjuade en tolkningshorisont när de identifierat allianser. Om de uppfattat att någon i de andras allians befunnit sig högre upp i en "trovärdighetshierarki« tillskriver de sig själva rollen som en mindre resursstark person. I intervjumaterialet har definitionerna handlat om att genom de andras ögon uppleva sig själv klassificerad som (alltför) ung, inte "svensk som de andra« eller - som visas nedan - (dålig) kvinna och (avvikande) homosexuell.

\section{Homosocialitet och en normativ heterosexualitet}

Då de intervjuade själva eller motparten i en rättegång får medhåll kan alliansen även motiveras med att det är ett uttryck för homosocialitet där de allierande väljer att tro och förstå varandra på grundval av gemensam könstillhörighet. Den målsägande (IP4, målsägande) som uppfattade att den tilltalade och domaren tillsammans förringade hennes berättelse genom skratt och skoj, säger att deras enighet varken rörde 
sakförhållanden eller gemensam humor, utan var uttryck för en manlig gemenskap hon som kvinna stod utanför. Upplevelsen av exkludering kontrasterar hon mot sin erfarenhet av hur en kvinnlig polis tog emot hennes anmälan och bekräftade henne med orden "det här hade kunnat hända mig också».

En intervjuperson (IP1, målsägande/ vittne), som både varit målsägande och vittnat, beskriver hur allianser i rättssalen kan bygga på heteronormativitet, dvs. uppfattningar om att heterosexualitet är det enda normala intima levnadssättet. Advokaten använde, enligt intervjupersonen, fördomsfulla uppfattningar om homosexualitet som ett sätt att devalvera hans vittnesmål. Även om bedömarna inte godtog denna strategi så upplevde vittnet det kränkande att domaren tillåtit argumentationen.

Vem jag är då, om jag är gay eller straight, var ju irrelevant /.../ Men domaren, eller nämndemännen, ingen av dem tycktes finna det irrelevant utan de lät ju frågan ställas. (IP1, målsägande/vittne)

En liknande heteronormativ allians kunde intervjupersonen tycka sig se då han skulle stödja en anhörig som vittnade i en hatbrottsrättegång. En grupp unga män stod åtalade för att ha mördat en homosexuell man. Intervjupersonen säger att männens försvarare strategiskt drev argumenten att "vi alla skulle förstå vilken chock det måste vara för två vanliga killar att helt plötsligt träffa en människa som inte döljer att han är gay“ (IP1, målsägande/vittne). Även vid denna rättegång säger intervjupersonen att juristdomaren lät advokaten ställa frågor som antydde misstänksamhet eller fördomar mot homosexuella. Intervjupersonen tolkade det som att domaren och advokaten ingått en allians på heteronormativa premisser eftersom "domaren talade upprepade gånger om offrets 'böjelser' " (IP1, målsägande/vittne).

\section{Avslutning}

Jag har pekat på hur målsägande, tilltalade och vittnen säger att de upplevt sig inkluderade eller exkluderade i olika allianser under de brottmålsrättegångar där de deltagit. I vissa fall har dessa allianser stämt överens med de rättsligt avsedda, i andra inte. Ett exempel på det senare är då de intervjuade uppfattat att såväl juristdomare, nämndemän, åklagare som advokat varit en allians av "bedömare». Detta samtidigt som att motparten, i form av tilltalad eller målsägande, har uppfattats som en lierad eftersom han eller hon också befunnit sig i en bedömningssituation.

Den identifikation av olika allianser som de intervjuade berättar att de gjort kan ge förståelse för hur människor använder sociala klassifikationer - i form av klass, kön, ras och sexualitet - som verktyg för att orientera sig i utsatta lägen. När denna sociala klassificering av "de andra" och en själv sker, görs samtidigt en bedömning av de egna förutsättningarna att bli trodd. Den berättelse som alliansens inkluderade ställer sig bakom växer i trovärdighet på bekostnad av den exkluderades utsaga, vilken uppfattas som mindre övertygande. Även i de fall då det förflutit lång tid sedan rättegången utspelat sig så uttrycker de intervjuade 
starka känslor där det framförallt är kränkningen av att exkluderas från iakttagna allianser som sägs ha varit mest smärtsam. Att uppfatta sig som exkluderad tycks vara förenat med känslan av att inte ha blivit tagen på allvar, medan den inkluderade fått gehör och blivit betraktad på ett komplext sätt. Det är också den exkluderande situationen som de intervjuade främst försöker att förklara.

Avishai Margalit (1998) har beskrivit en filosofisk vision om ett "anständigt» samhälle som inte kränker de individers mänskliga värde som står i ett beroendeförhållande till dess institutionella organ. Ett respektfullt eller anständigt "samhälle« måste utgå från att varje individ förtjänar aktning för sitt mänskliga värde, ett erkännande bortom prestationer och social status. I detta sammanhang utgör rättssystemet med dess straff, enligt Margalit (1998 s. 237), "det anständiga samhällets lackmustest». Att arbeta för respektfullt bemötande, oavsett domens utfall, torde utifrån detta synsätt vara en angelägenhet i brottmålsrättegångar. De målsägande, tilltalade och vittnen som intervjuats uttrycker också en längtan efter respekt i form av uppriktigt, ömsesidigt lyssnande. De lyfter fram betydelsen av tillfälliga situationer då någon bekräftat dem genom att lyssna på deras berättelse.

Dilemmat i rättegångarna verkar dock handla om alliansernas nollsummespel, d.v.s. att den egna inkluderingen för andra tycks bli den kränkning aktören själv undgått. Man kan därför fråga sig om en situation helt fri från allianser är den enda förutsättningen för ett kränkningsfritt sammanhang. Men då brottmålsrättegångar så ofta grundas i konfliktsituationer förefaller ett sådant tillstånd som något orealistiskt. Kanske hanteras dilemmat snarare genom att öka medvetenheten om den betydelse som upplevelser av inkludering eller exkludering kan ha för enskilda berörda parter.

\section{Referenser}

Becker, H. S. (1998) Tricks of the Trade. How to Think about Your Research While You're Doing It. Chicago: University of Chicago Press.

Berger, P. L. (1992) Invitation till sociologi. Ett humanistiskt perspektiv. Stockholm: Rabén \& Sjögren.

Berger, P. L. \& Luckman, T. (2003) Kunskapssociologi. Hur individen uppfattar och formar sin sociala verklighet. Falun: Wahlström \& Widstrand.

Bourdieu, P. (1996) Homo academicus. Stockholm: Brutus Östlings bokförlag.
Christie, N. (1996) „Moderniserad legalitet». I M. Åkerström (red.) Kriminalitet, kultur, kontroll. En antologi. Stockholm: Carlsson Bokförlag.

Christie, N. (2001) "Det idealiska offret». I M. Åkerström \& I. Sahlin (red.) Det motspänstiga offret. Lund: Studentlitteratur.

Corbin, J. \& Strauss, A. (1990) Basics of Qualitative Research: Grounded Theory Procedures and Techniques. Newbury Park, California: SAGE.

Ekström, S. (2002) Trovärdighet och ovärdighet. Rättsapparatens hanterande av kvinnors anmälan. Hedemora: Gidlunds förlag. 
Emerson, R. M. (1996) „Konstruktionen av grovt våld och våldsoffer. Att framställa ett besöksförbud». I M. Åkerström (red.) Kriminalitet, kultur, kontroll. En antologi. Stockholm: Carlsson Bokförlag.

Goffman, E. (2000) Jaget och maskerna. En studie av vardagslivets dramatik. Stockholm: Prisma.

Honneth, A. (2003) Erkännande. Praktisk-filosofiska studier. Göteborg: Daidalos.

Hydle, I. (2000) "Mord utan motiv? En antropologisk studie av en brottmålsprocessu. I I. Sahlin, \& M. Åkerström (red.) Det lokala våldet. Om rädsla, rasism och social kontroll. Stockholm: Liber.

Jacobsson, C. (2006) „Vi kan inte göra hipp som happ'. Åklagares formuleringar av en objektiv sanning". Sociologisk forskning nr 2, s. 31-61.

Katz, J. (1988) Seduction of Crime. Moral and Sensual Attractions in Doing Evil. New York: Basic Books.

Katz, J. (1996) „Kriminalitetens lockelser och reformvännernas dilemma». I M. Åkerström (red.) Kriminalitet, kultur, kontroll. En antologi. Stockholm: Carlsson Bokförlag.

Katz, J. (1999) How Emotions Work. Chicago: University of Chicago Press.

Lindstedt Cronberg, M. (2002) „Från målsägande till brottsoffer». I E. Bergenlöv, M. Lindstedt Cronberg, \& E. Österberg Offer för brott. Våldtäkt, incest och barnamord $i$ Sveriges historia från reformationen till nutid. Lund: Nordic Academic Press.

Löfstrand, C. (2005) Hemlöshetens politik. Lokal policy och praktik. Malmö: Égalité.
Margalit, A. (1998) Det anständiga samhället. För en värdighetens politik. Göteborg: Daidalos.

Sahlin, I. (1994) "Stackare» eller »skurk». Om den kluvna klientbilden. Research Report 1994:1. Network for Research in Criminolgy and Deviant Behaviour at Lund University.

Sahlin, I. (1998) „Besöksförbud och målsägandebiträde. Brottsoffers erfarenheter» Bilaga 8. I Brottsoffer. Vad har gjorts? Vad bör göras? SOU 1998:40.

Sahlin, I. (2008) „Om trovärdighet i ändrade berättelser". Retfaerd31 nr 4/123, s. 61-82.

Scheppele, K. L. (1994) „Practices of Truth Finding in a Court of Law. The Case of Revised Storiesw. I T. Sarbin \& J. Kitsuse (eds.) Constructing the social. London: SAGE Publ.

Sennett, R. (2007) Den nya kapitalismens kultur. Stockholm: Atlas.

Strömwall, L. \& Granhang, P. A. (2003) "How to Detect Deception? Arresting the Belifs of Polce Officers, Prosecutors and Judges". Psychology, Crime \& Law vol. 9, s. 19-36.

Strömwall, L. A. Granhang, P. A. \& Hartwig M. (2004) „Practioners' beliefs about deception«. I L. A. Strömwall \& P. A. Granhag The Detection of Deception in Forensic Contexts. Cambridge: University Press.

Viano, E. C. (1996) „Stereotyping and Prejudice. Crime victims and the criminal justice system". Studies on crime and crime prevention, 5 (2), s. 182-202.

Åkerström, M. (1996) "Inledning«. I M. Åkerström (red.) Kriminalitet, kultur, kontroll. En antologi. Stockholm: Carlsson Bokförlag. 


\section{Summary}

\section{Perceiving alliances - a way to handle uncertainty}

This article is based upon interviews with prosecutors, defendants and witnesses, who say that during court proceedings they have identified alliances between other participants. The interviewees understood phrases, gestures, laughter and positions taken in the courtroom as a pretext for creation of alliances and explain the perceived fellowship as a result of social homogeneity grounded in categories such as class, gender, sexuality or ethnicity. The understanding of these issues or codes of performance that allegedly unify other actors is here seen as a strategy to create security in uncertain and unfamiliar situations. In this perspective we may say that structural explanations help the interviewee to account for feeling excluded or regarded as untrustworthy. At the same time as alliances are categorized, the individuals construct - as if through the eyes of "the others" - an image of themselves as deviant with regard to race, generation or sexuality. Whether or not the alliances of "the others" had an influence on the judgment, or were aimed to do so, these perceived alliances and their expressions occasionally made the interviewees feel uncomfortable and excluded, and some of them claimed that this sense of being excluded or disrespected had lasted for a long time after the court proceedings. 